\title{
EVALUATION OF UREA SUPER GRANULE AS A SOURCE OF NITROGEN IN TRANSPLANT AMAN RICE
}

\author{
T. A. Qurashi, M. A. Salam, M. Jannat and M. G. Rabbani \\ Department of Agronomy, Bangladesh Agricultural University \\ Mymensingh-2202, Bangladesh
}

\begin{abstract}
An experiment was carried out at Bangladesh Agricultural University, Mymensingh to evaluate the effect of urea super granule (USG) as a source of nitrogen on the yield and yield components of transplant Aman rice cv. BRRI dhan39, BRRI dhan46 and BINA dhan7. Five levels of N (viz., 0, 60, $120 \mathrm{~kg} \mathrm{ha}^{-1}$ as prilled urea and 60 and $120 \mathrm{~kg} \mathrm{ha}^{-1}$ as USG) were taken as experimental treatments. The experiment was laid out in a randomized complete block design with three replications. Plant height, effective tillers hill-1, grains panicle ${ }^{-1}$ and grain yield varied significantly due to different cultivars. All the yield and yield components except 1000-grain weight were influenced significantly by the levels of nitrogen fertilizer. The highest grain yield $\left(4.82 \mathrm{t} \mathrm{ha}^{-1}\right)$ was recorded in BINA dhan7 and the lowest one (4.30 $\left.\mathrm{t} \mathrm{ha}^{-1}\right)$ was recorded in BRRI dhan39. Nitrogen @ $120 \mathrm{~kg} \mathrm{ha}^{-1}$ as USG performed the best among the treatments in respect of yield and yield components of rice. The highest grain yield $\left(5.46 t \mathrm{ha}^{-1}\right)$ was obtained from BINA dhan7 with $120 \mathrm{~kg} \mathrm{~N}^{-1}$ as USG which was statistically identical with $60 \mathrm{~kg} \mathrm{~N} \mathrm{ha-1}$ as USG. A considerable amount (31.25\%) of prilled urea (PU) nitrogen could be saved by using USG. It may be concluded that USG could be used as $\mathrm{N}$ management to achieve better nitrogen use efficiency in reducing $\mathrm{N}$ loss than the PU.
\end{abstract}

Key Words: Nitrogen use efficiency, Urea super granule, Transplant Aman rice, Yield

\section{INTRODUCTION}

Rice (Oryza sativa L.) is the staple food and major cereal crop of Bangladesh. It is the extensively cultivated crop for half of the world's population (FAO, 2010). It is grown throughout the year in the country, but the average yield of rice in Bangladesh is much lower (2.94 $\left.\mathrm{t} \mathrm{ha}^{-1}\right)$ (BBS, 2012) than other rice producing countries of the world like Japan (6.8 t/ha), Korea (6.8 t/ha) and China (6.3 t/ha) (IRRI, 2005). Among the various reasons for low yield judicious fertilizer management is one of them. Among the fertilizers nitrogen is the major essential plant nutrient and key input for rice production and increasing yield in the rice growing countries as well in Bangladesh, which can augment the production of rice to a great extent (Hasan et al., 2002). Application of urea-N plays a vital role in vegetative growth, development and yield of rice. Yield increase $70-80 \%$ of field rice could be obtained by the application of nitrogenous fertilizer (IFC, 1982). From previous studies it was observed that rice had optimum growth and development with optimum nitrogen applied giving maximum filled grain percentage, 1000-grain weight and grain and straw yields 
(Kumar et al., 1999). Gately and Singh (1987) stated that the types of nitrogenous fertilizer might also affect the yield and quality of the rice grain. According to Crasswell and De Datta (1980), broadcast application of urea on the surface soil causes losses up to $50 \%$ but point placement of urea super granules (USG) at $10 \mathrm{~cm}$ depth may result in negligible loss. USG is a fertilizer that can be applied in the rice root zone at 8-10 cm depth of soil (reduced zone of rice soil) which can save 30\% nitrogen than prilled urea, increase absorption rate, improve soil health and ultimately increase the rice yield (Savant et al., 1991). It is observed from the literature that nitrogen use efficiency of rice could be increased by root zone placement of USG as it would reduce the magnitude of nitrogen losses to a considerable extent and increase its use efficiency for better grain production (Crasswell and De Datta, 1980). Variety is the most important factor in rice production. Use of high yielding variety (HYV) has been increased remarkably in recent years and the country has almost reached a level of self sufficiency in food. The lion share of this self sufficiency is obtained through the expansion of HYV rice cultivation. Some reasons of this higher production may be due to high response to fertilizer, especially $\mathrm{N}$ fertilizer. Selection of potential variety, planting in appropriate method and application of optimum amount of nutrient elements, can play an important role in increasing yield and national income. From the above discussion it is clear that USG is an important source of nitrogen and has great impact for increasing the nitrogen use efficiency and yield of rice. It is known that the response of crops to nitrogen varies due to variety. So it is essential to investigate the response of HYV rice varieties to different doses of urea super granules. In view of the above discussion the present study was, therefore, undertaken to evaluate the USG as a source of nitrogen in different T. Aman rice varieties, to find out the optimum dose of USG for higher yield of T. Aman rice, to see the effect of cultivars on the performance of T. Aman rice yield and yield contribution characters.

\section{MATERIALS AND METHODS}

The experiment was carried out at the Agronomy Field Laboratory of Bangladesh Agricultural University, Mymensingh during July to December 2012 to evaluate USG as a source of nitrogen in transplant Aman rice cv. BRRI dhan39, BRRI dhan46 and BINA dhan7. The study consisted of two factors. Factor A- Variety (i) BRRI dhan39, (ii) BRRI dhan46 and (iii) BINA dhan7 and Factor B- Sources and doses of nitrogen (i) $0 \mathrm{~kg} \mathrm{~N} \mathrm{ha}^{-1}$, (ii) $60 \mathrm{~kg} \mathrm{~N}$ ha ${ }^{-1}$ as PU, (iii) $120 \mathrm{~kg} \mathrm{~N}^{-1}$ as PU, (iv) $60 \mathrm{~kg} \mathrm{~N} \mathrm{ha}^{-1}$ as USG (0.9 g) and (v) $120 \mathrm{~kg} \mathrm{~N}^{-1}$ as USG (1.8g). The experiment was laid out in a randomized complete block design with three replications. The soil of the experimental field was more or less neutral in reaction with $\mathrm{pH}$ value 6.5 , low in organic matters content $(1.1 \%)$ and the general fertility level of the soil was also low. Healthy seeds of each cultivar were selected for raising seedlings. High land was selected at the Agronomy Field Laboratory, Bangladesh Agricultural University, Mymensingh for raising seedling. The field layout was made on 22 July 2012 according to experimental specification immediately after final land preparation. Weeds and stubbles were cleaned off from individual plots and finally plots were leveled properly by wooden plank in such a manner that no water pocket could remain in the puddle field. Whole amount of triple superphosphate, muriate of potash and gypsum were broadcast and incorporated into the soil at final land preparation @ $60 \mathrm{~kg}, 70 \mathrm{~kg}$, and $60 \mathrm{~kg} \mathrm{ha}^{-1}$, 
respectively and nitrogen was applied according to experimental specification in the form of prilled urea. After 7 days of transplanting pellets of USG $0.9 \mathrm{~g}\left(60 \mathrm{~kg} \mathrm{~N} \mathrm{ha}^{-1}\right)$ and $1.8 \mathrm{~g}(120 \mathrm{~kg}$ $\mathrm{N} \mathrm{ha}^{-1}$ ) were placed manually in the root zone at 8-10 $\mathrm{cm}$ depth of the soil at the centre of four hills of two adjacent rows. One month aged seedlings were transplanted on well puddled plots on 24 July 2012 according to the experimental design. Three seedlings were transplanted in each hill with a spacing of $25 \mathrm{~cm} \times 15 \mathrm{~cm}$. The plots were kept weed free by hand pulling. Due to frequent raining during crop growth period, no irrigation was needed. Excess water was drained out from the plots in due time before harvesting. No remarkable infestation of insects and diseases was noticed in the field. So, no plant protection measures were taken. Five hills (excluding border hills) from each plot were randomly selected, uprooted and properly tagged before harvesting for recording necessary data on yield contributing characters. Maturities of crops were determined when $90 \%$ of the grains become golden yellow in color. The crop was harvested at full maturity on different dates as per to the variety of rice. The harvested crop of each plot was bundled separately, tagged properly and brought to the clean threshing floor. The bundles were dried in open sunshine, threshed and then seeds were cleaned. The grain and straw weights for each plot were recorded after proper sun drying. The grain yield was adjusted to $14 \%$ moisture content. Grain and straw yield per plot were converted to ton per hectare. The collected data were analyzed statistically following the ANOVA technique and the mean differences were adjudged by Duncan's Multiple Range Test (Gomez and Gomez, 1984) using a statistical computer package program MSTAT-C.

\section{RESULTS AND DISCUSSION}

\section{Effect of variety}

Variety showed significant influence on all the yield and yield contributing characters of transplant Aman rice except straw yield and harvest index (Table 1). BRRI dhan46 produced the tallest plant $(112.29 \mathrm{~cm})$ and the shortest plant $(92.21 \mathrm{~cm})$ was obtained from BINA dhan7. The highest number of effective tillers hill-1 ${ }^{-1}$ was produced by BINA dhan7 (9.05) and the lowest one (7.42) was produced by BRRI dhan39. The probable reason of the differences in producing the effective tillers hill- ${ }^{-1}$ is the genetic make-up of the variety which is primarily influenced by heredity. This finding corroborates with the findings of BINA (1998), Om el al. (1998) and Bhowmick and Nayak (2000) who stated that effective tillers hill1 varied due to variety. BRRI dhan39 produced the longest panicle $(24.51 \mathrm{~cm})$ and BINA dhan7 produced the shortest panicle. Table I shows that BINA dhan7 produced the highest number of grains panicle-1 (143.30) and BRRI dhan39 produced minimum number of grains panicle $^{-1}$ (128.39). Srivastava and Thipathi (1998), Bhowmick and Nayak (2000) also reported that number of grains panicle ${ }^{-1}$ varied among the varieties. Among the undesirable traits considered, number of sterile spikelets panicle ${ }^{-1}$ is the most significant one and plays a vital role in yield reduction. Number of sterile spikelets panicle-1 was significantly influenced among the varieties studied. BRRI dhan39 produced the highest number of sterile spikelets panicle $^{-1}$ (17.93) and BINA dhan7 produced the lowest number of sterile spikelets panicle ${ }^{-1}$ (13.17). Chowdhury el al. (1993) also observed differences in number of sterile spikelets panicle $^{-1}$ due to varietal differences. The highest 1000 -grain weight $(23.38 \mathrm{~g})$ was obtained from the variety BRRI dhan 46 which was statistically identical with that of BRRI dhan39. 
The lowest 1000-grain weight $(22.77 \mathrm{~g})$ was obtained from BINA dhan7. These results are in agreement with Shamsuddin el al. (1988) and Chowdhury et al. (1993) who reported difference in 1000-grain weight among the varieties. BINA dhan7 produced the highest grain yield $\left(4.82 \mathrm{tha}^{-1}\right)$ followed by BRRI dhan $46\left(4.56 \mathrm{tha}^{-1}\right)$ and the lowest grain yield (4.30 $\mathrm{t} \mathrm{ha}^{-1}$ ) was obtained from BRRI dhan39. Varietals differences regarding grain yield was also reported by Patel (2000). The highest grain yield in BINA dhan7 was the consequence of highest number of effective tillers hill- ${ }^{-1}$ and highest number of grains panicle-1. Harvest index was not significantly influenced by different varieties, numerically the highest harvest index $(47.79 \%)$ was obtained from the variety BINA dhan7 and the lowest one $(45.79 \%)$ was obtained from BRRI dhan39.

\section{Effect of different doses and sources of nitrogen}

Different doses and sources of nitrogen had significant effect on all the yield and yield contributing characters of rice except 1000-grain weight (Table 2). The tallest plant (107.14 $\mathrm{cm}$ ) was produced from $120 \mathrm{~kg} \mathrm{~N}^{-1}$ as prilled urea which was statistically identical with $120 \mathrm{~kg} \mathrm{~N} \mathrm{ha}^{-1}$ (106.63) as USG, and the shortest plant $(102.30 \mathrm{~cm})$ was produced from $0 \mathrm{~kg} \mathrm{~N}$ $\mathrm{ha}^{-1}$. In general the number of total tillers hill-1 increased with increasing the levels of USG. Table 2 shows that the highest number of total tillers hill-1 (13.24) was produced when 120 $\mathrm{kg} \mathrm{N} \mathrm{ha}^{-1}$ was applied as USG and the lowest one (8.35) was recorded from $0 \mathrm{~kg} \mathrm{~N}^{-1}$. The progressive improvement in the formation of tillers might be due to the use of efficiency of nitrogen, which enhanced tillering. Number of effective tillers hill-1 was significantly influenced by the source and dose of nitrogen. Results show that USG @ 120 kg N ha-1 performed the highest number of effective tillers hill-1 (11.12) and the lowest one (4.97) was obtain from $0 \mathrm{~kg} \mathrm{~N} \mathrm{ha}^{-1}$. Adequacy of nitrogen as USG probably favored the cellular activities during panicle initiation and development which led to increase number of productive tillers hill-1. Similar research finding was also reported by Singh and Singh (1986). Table 2 shows that the longest panicle $(23.83 \mathrm{~cm})$ was produced when USG was applied @ $60 \mathrm{~kg} \mathrm{~N} \mathrm{ha}^{-1}$ and the shortest panicle $(22.45 \mathrm{~cm})$ was produced when no urea was applied $\left(0 \mathrm{~kg} \mathrm{~N} \mathrm{ha}^{-1}\right)$. The highest number of grains panicle-1 (154.35) was obtained from 120 $\mathrm{kg} \mathrm{N} \mathrm{ha-1}$ as USG and the lowest one (110.59) was recorded from $0 \mathrm{~kg} \mathrm{~N} \mathrm{ha}^{-1}$. Adequate supply of nitrogen as USG contributed to grain formation which probably increased number of grains panicle ${ }^{-1}$ with optimum level of nitrogen. The grain yield of transplant ainan rice was the highest (5.24 tha-1) with $120 \mathrm{~kg}$ nitrogen ha-1 as USG. The second highest grain yield (4.90 $\left.\mathrm{tha}^{-1}\right)$ was obtained from $120 \mathrm{~kg} \mathrm{~N}^{-1}$ applied as PU. These results are in agreement with those obtained by Singh and Mahapatra (1989), Raja el al. (1987) who recorded the highest grain yield from $120 \mathrm{~kg} \mathrm{~N}^{-1}$ as USG and $120 \mathrm{~kg} \mathrm{~N}^{-1}$ as PU respectively. The highest straw yield $\left(5.95 \mathrm{tha}^{-1}\right)$ was produced by $120 \mathrm{~kg} \mathrm{~N} \mathrm{ha}^{-1}$ as USG and the lowest straw yield $\left(4.58 \mathrm{tha}^{-1}\right)$ was obtained from $0 \mathrm{~kg} \mathrm{~N}^{-1}$. Higher dose of nitrogen influenced vegetative growth in terms of plant height which resulted in differences of straw yield. These findings corroborate with that of Quayum and Prasad (1994). The highest harvest index (49.43\%) was recorded from $60 \mathrm{~kg} \mathrm{~N} \mathrm{ha}^{-1}$ as USG and the lowest one (42.48\%) was obtained $0 \mathrm{~kg} \mathrm{~N} \mathrm{ha-1}$. 

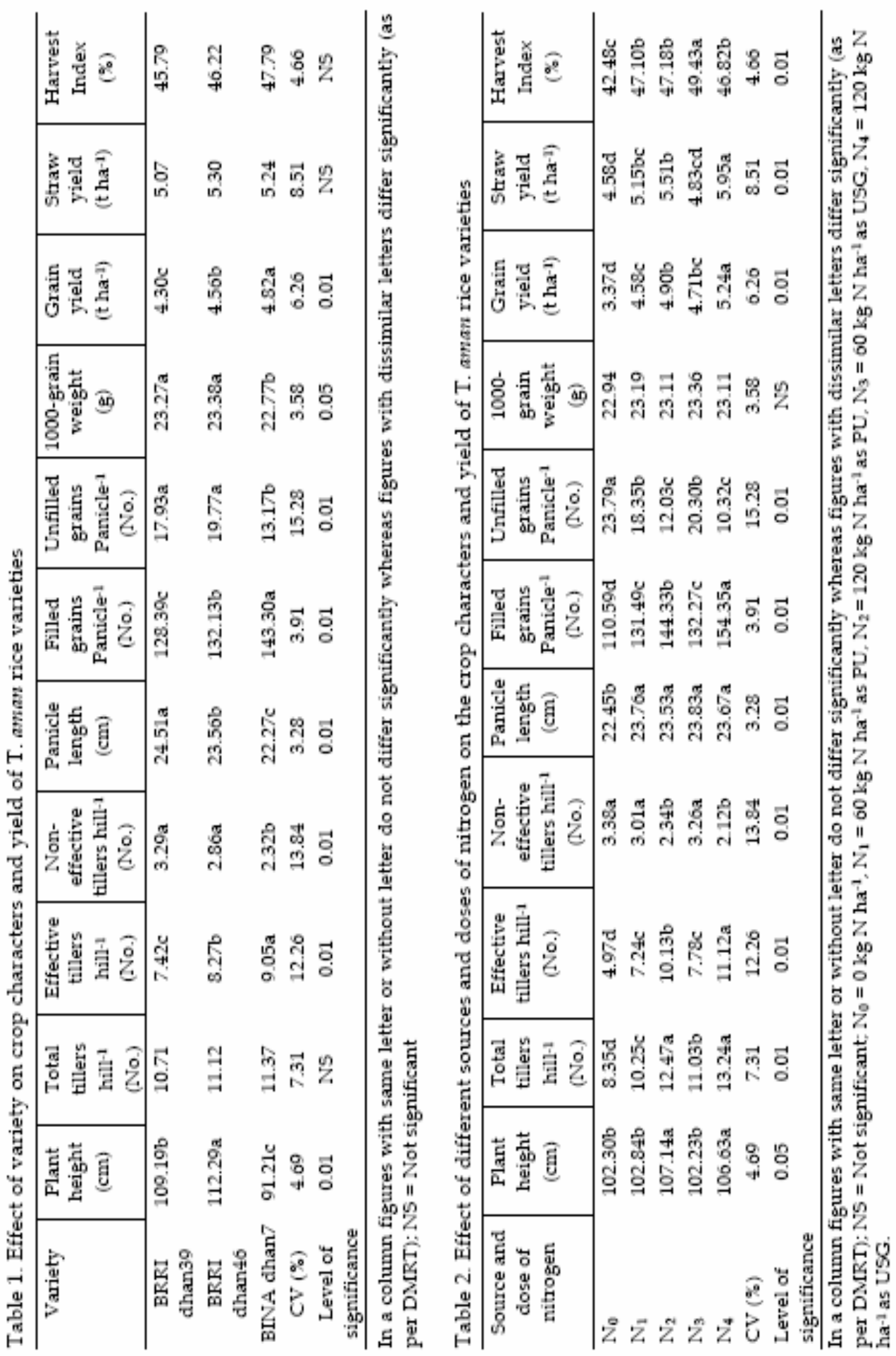
Interaction effect of variety and doses and sources of nitrogen

Interaction of variety and doses and sources of $\mathrm{N}$ has significant effect on most of the yield and yield contributing characters of transplant Aman rice (Table 3). There was significant difference in plant height due to interaction of variety and source and doses of nitrogen. The tallest plant $(115.50 \mathrm{~cm})$ was obtained due to the interaction of BRRI dhan $46 \times 120 \mathrm{~kg} \mathrm{~N} \mathrm{ha}^{-1}$ as prilled urea a well as BRRI dhan $46 \times 60 \mathrm{~kg} \mathrm{~N} \mathrm{ha}^{-1}$ applied as USG. The shortest plant $\left(83.47 \mathrm{~cm}\right.$ ) was obtained due to the interaction of BINA dhan7 $\times 60 \mathrm{~kg} \mathrm{~N} \mathrm{ha}^{-1}$ applied as

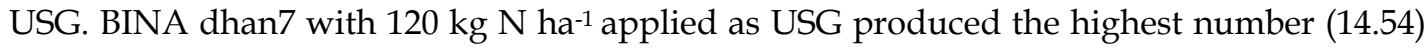
of total tillers hill-1. BINA dhan7 with $0 \mathrm{~kg} \mathrm{~N}^{-1} \mathrm{a}^{-1}$ produced the lowest (7.58) number of total tillers hill-1. This might be due to the nitrogen use efficiency of varieties from different sources. The results reveal that the effect of interaction between variety and nitrogen was found to be significant in respect of number of effective tillers hill-1 ${ }^{-1}$. The highest number of effective tillers hill-1 (12.97) was recorded from the treatment combination of BINA dhan7 $\times$ $120 \mathrm{~kg} \mathrm{~N} \mathrm{ha}^{-1}$ applied as USG. The result shows that interaction between BINA dhan7 and I20 $\mathrm{kg} \mathrm{N} \mathrm{ha}^{-1}$ as USG was found to be the best in respect of number of grains panicle-1 (163.02), on the other hand the lowest number of grains panicle-1 (101.34) was obtained from the interaction between BRRI dhan39 and $0 \mathrm{~kg} \mathrm{~N} \mathrm{ha}^{-1}$. Nitrogen took part both in grain formation and development and for this reason number of grains panicle ${ }^{-1}$ increased with adequate level of N. From Table 3, it is observed that the highest grain yield (5.46 $\left.\mathrm{tha}^{-1}\right)$ was recorded in the treatment combination of BINA dhan7 $\times 120 \mathrm{~kg} \mathrm{~N} \mathrm{ha}^{-1}$ applied as USG which was statistically identical with variety BINA dhan7 $\times 60 \mathrm{~kg} \mathrm{~N} \mathrm{ha}^{-1}$ applied as USG. The lowest grain yield was recorded with the treatment combination of BRRI dhan $39 \times 0 \mathrm{~kg}$ $\mathrm{N} \mathrm{ha}^{-1}$. The highest straw yield $\left(6.06 \mathrm{t} \mathrm{ha}^{-1}\right)$ was obtained from the combination of BRRI dhan39 $\times 120 \mathrm{~kg} \mathrm{~N} \mathrm{ha}^{-1}$ as USG and the lowest straw yield $\left(4.17 \mathrm{t} \mathrm{ha}^{-1}\right)$ was recorded in BINA dhan7 $\times 60 \mathrm{~kg} \mathrm{~N} \mathrm{ha}^{-1}$ as USG (Table 3). The highest harvest index, (56.47\%) was recorded from BINA dhan7 with $60 \mathrm{~kg} \mathrm{~N} \mathrm{ha}^{-1}$ as USG. The lowest harvest index (40.24 \%) was obtained from BINA dhan7 $\times 0 \mathrm{~kg} \mathrm{~N} \mathrm{ha-1}$.

From the above discussion, among the varieties studied, BINA dhan7 performed the best regarding grain yield. Moreover, BINA dhan7 and BRRI dhan39 matured 15 days earlier than BRRI dhan46. It is observed that using USG, maximum N was taken up by rice plant to convert it into dry matter for producing grains. As a result, maximum utilization of $\mathrm{N}$ was possible due to proper application of N as USG placement. Therefore, USG might be used as $\mathrm{N}$ management to achieve better nitrogen use efficiency without reducing yield and reducing nitrogen loss than PU. From the results of the study it may be concluded that variety BINA dhan7 with $60 \mathrm{~kg} \mathrm{~N}$ ha-1 $^{-1}$ as USG will be the economic for production of transplant Aman rice since BINA dhan7 with $120 \mathrm{~kg} \mathrm{~N} \mathrm{ha}^{-1}$ or $60 \mathrm{~kg} \mathrm{~N} \mathrm{ha}^{-1}$ applied as USG produced the statistically identical grain yield. 


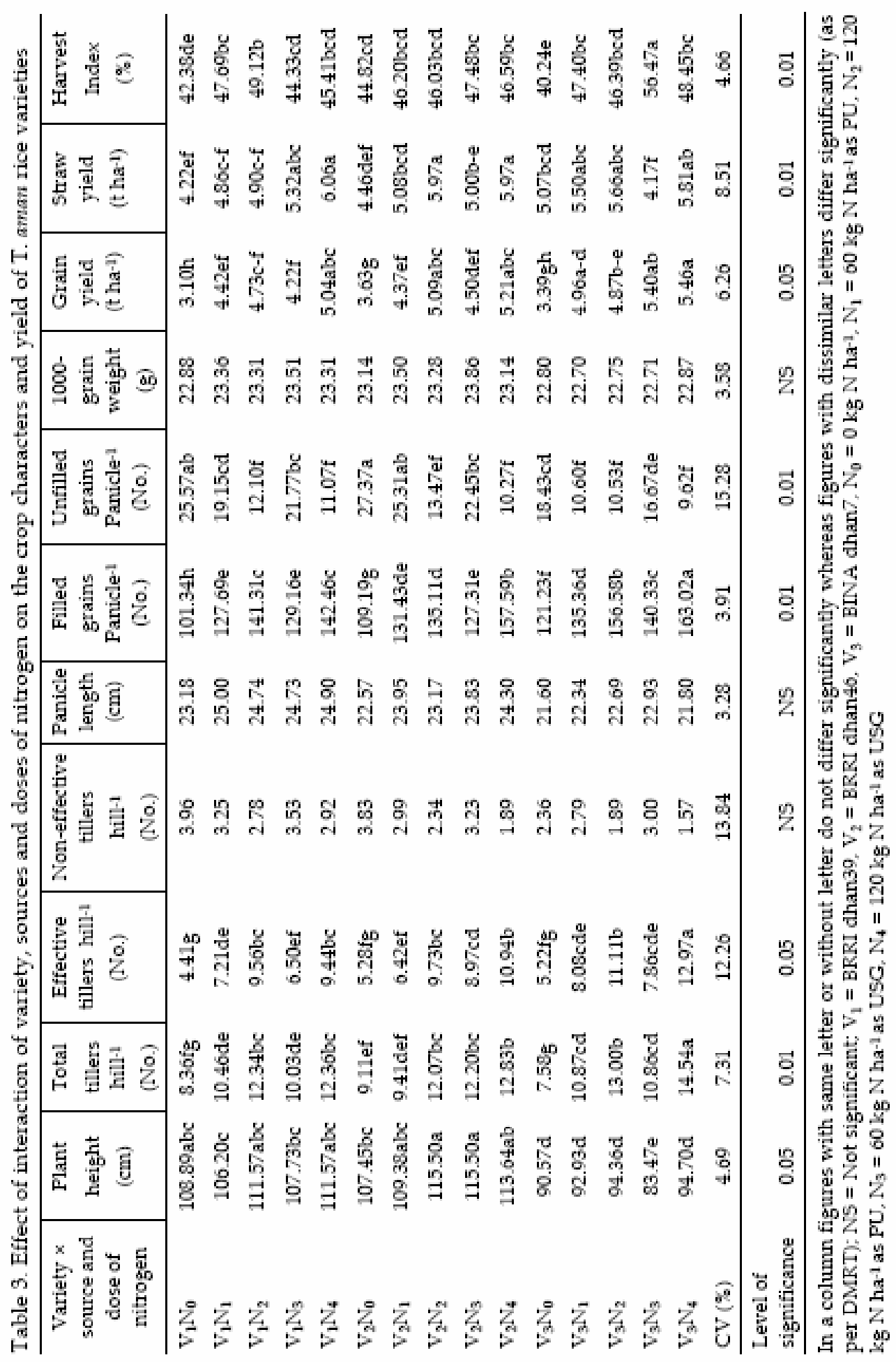




\section{REFERENCES}

Ahmed, M. H., Islam, M.A., Kader, M. A. and Anwar, M.P. 2000. Evaluation of urea super granules as a source of nitrogen in transplant Aman rice. Pakistan J. Biol. Sci., 3(5): 735-737.

BBS (Bangladesh Bureau of Statistics). Statistical Year Book of Bangladesh. 2012. Bangladesh Bureau of Statistics. Stat. Div. Ministry of Planning. Govt. Peoples Repub. Bangladesh. pp. 33-36.

Bhowmick, N. and Nayak, R. L. 2000. Response of hybrid rice (Oryza sativa L.) varieties to nitrogen, phosphorus and potassium fertilizers during dry season in West Bengal. Indian J. Agron., 45(2): 323-326.

BINA (Bangladesh Institute of Nuclear Agriculture). 1998. Annual Report for 1993-1994. Bangladesh Inst. Nuc. Agric. P.O. Box No. 4, Mymensingh-2202. p. 175.

Chowdhury, M. J. U., Sarker, A. U., Sarkar, M. A. R. and Kashem, M. A. 1993. Effect of variety and number of seedlings hill-1 on the yield and its components on late transplanted Aman rice. Bangladesh J. Agril. Sci., 20(2): 311-316.

Crassswell, E. T. and De Datta, S. K. 1980. Recent Development in research on nitrogen fertilizers for rice. Indian J. Agron., 31(4): 387-389.

FAO. 2010. Crop Prospects and Food Situation. FAO Annual Report No. 2. Rome, Italy.

Gately, V. P. and Singh, G. R. 1987. Performance of urea super granule and prilled urea under different planting methods in irrigated rice (Oryza sativa L.). Indian J. Agric. Sci., 71(3): 187-189.

Gomez, K. A. and Gomez, A. A. 1984. Statistical Procedures for Agricultural Research. Intl. Rice Res. Inst., John Wiley and Sons, New York, Chickester, Brisbane, Toronto, Singapore. p. 680.

Hasan, M. S., Hossain, S. M. A., Salim, M., Anwar, M. P. and Azad, A. K. M. 2002. Response of hybrid and inbred rice varieties to the application methods of urea super granules and grilled urea. Pakistan J. Biol. Sci., 5(7): 746-748.

IFC (International Fertilizer Council). 1982. Physiology of crop plants. Iowa State Press, Iowa. p. 66.

IRRI (International Rice Research institute). 2005. Rice Production and Market: Trend and Outlook. In: IFA Regional Conference for Asia and the Pacific. Hossain, M. (ed.). Singapore, 6-8 December 2005. Intl. Rice Res. Inst. Los Banos, The Philippines.

Kumar, V. J. F., BalasubrAmanian, M. and Jesudas, D. M. 1999. Application of different forms of urea for rice. J. Indain Soc. Soil Sci., 44(2): 267-270.

Om, H., Dhiman, S. D., Nandal, D. P. and Verma, S. L. 1998. Effect of method of nursery raising and nitrogen on the growth and yield of hybrid rice (Oryza sativa L.). Indian J. Agron., 43(1): 68-70.

Patel, J.R. 2000. Effect of water regime, variety and blue green algae on hybrid rice (Oryza sativa L.). Indian J. Agron., 45(1): 103-106.

Quayum, A. and Prasad, K. 1994. Performance of modified urea materials in rainfed lowland rice (Oryza sativa L.). J. Res. Birsa Agric. Univ., 6(2): 131-134. 
Raja, R. A., Hussain, M. M., and Reddy, M. N. 1987. Relative efficiency of modified urea materials for lowland rice. Indian J. Agron., 32(4): 460-462.

Savant, N. K., Dhane, S. S. and Talashikar, S. C., 1991. Fertilizer News. Intl. Fert. Dev. Centre, Muscle, Shoals, Alabama, USA. 36(3): 19-25.

Shamsuddin, A. M., Islam, M. A. and Hossain, A. 1988. Comparative study on the yield and agronomic characters of nine cultivars of aus rice. Bangladesh J. Agril. Sci., 15(1): 121-124. 5(12): 10-17.

Singh, I. C. and Mahapatra, I. C. 1989. Economic use of fertilizers. Fertilizer Marketing Newsl.

Singh, B. K. and Singh, R. P. 1986. Effect of modified urea materials on rainfed lowland transplanted rice and their residual effect on succeeding wheat crop. Indian J. Agron., 31(2): 198-2000.

Srivastava, O. K. and Tripathi, R. S. 1998. Response of hybrid and composite rice to number of seedlings and plant geometry. Ann. Agril. Res. Newsl., 235-236. 